CENDEKIA UTAMA

Jurnal Keperawatan dan

Kesehatan Masyarakat

STIKES Cendekia Utama Kudus
P-ISSN 2252-8865

E-ISSN 2598-4217

Vol 10, No 2 Juli, 2021

Tersedia Online:

htpp://jurnal.stikescendekiautamakudus.ac.id

\title{
HUBUNGAN DUKUNGAN KELUARGA DENGAN UPAYA PERAWATAN KESEHATAN LANJUT USIA HIPERTENSI DIMASA PANDEMI COVID-19
}

\author{
Edy Soesanto \\ Universitas Muhammadiyah Semarang \\ edysoes@unimus.ac.id
}

\begin{abstract}
ABSTRAK
Kejadian hipertensi di dunia diprediksikan akan meningkat setiap tahunnya dan mencapai 29,2\% pada tahun 2025. Hipertensi dapat mengancam kesehatan masyarakat khususnya lanjut usia karena mempunyai potensi yang dapat menyebabkan komplikasi seperti stroke, jantung koroner dan gagal ginjal sehingga memerlukan pengobatan secara rutin. Usia lanjut dan hipertensi merupakan salah satu kondisi yang dianggap sebagai komorbid COVID-19, sehingga dapat meningkatkan tingkat keparahan dan kematian pada seseorang. Dukungan keluarga sangat dibutuhkan oleh penderita hipertensi agar dapat melaksanakan rencana perawatan yang telah ditetapkan dan mematuhi aturan terapinya khususnya dimasa pandemi COVID-19. Penelitian ini bertujuan untuk melihat adanya Hubungan Dukungan Keluarga Dengan Upaya Perawatan Kesehatan Lanjut usia Hipertensi Dimasa Pandemi COVID-19. Jenis penelitian ini adalah Deskriptif Korelasi dengan menggunakan desain Cross Sectional. Jumlah sampel sebanyak 96 responden lanjut usia yang menderita hipertensi di desa Kangkung, Mranggen, Demak, berusia $\geq 60$ tahun, sedang menjalani terapi anti hipertensi, rutin melakukan pengobatan hipertensi di Puskesmas Mranggen I dan tinggal bersama keluarga. Teknik pengambilan sampel dengan menggunakan Teknik proporsional random sampling. Alat pengumpulan data menggunakan kuesioner dan dianalisis dengan menggunakan uji Chi Square. Hasil penelitian menunjukkan bahwa terdapat 66 responden $(68,75 \%)$ telah melakukan upaya perawatan kesehatan dengan baik. Terdapat dukungan keluarga yang baik sebesar 85 responden (88,55 ada hubungan antara dukungan keluarga dengan upaya perawatan kesehatan lanjut usia hipertensi dimasa pandemi COVID-19 dengan nilai $\mathrm{p}$ value sebesar $\mathrm{p}=0,048$ ( $\mathrm{p}$ value $<0,05$ ). Berdasarkan hasil tersebut diharapkan lanjut usia hipertensi penderita agar tetap teratur melakukan upaya perawatan kesehatan khususnya kontrol rutin di pelayanan kesehatan meskipun dalam keadaan pandemi COVID-19 dengan memperhatikan protokol kesehatan sehingga dapat mencegah kemungkinan terjadinya komplikasi. Keluarga selalu memberikan motivasi dan dukungan kepada lanjut usia hipertensi untuk selalu melakukan upaya perawatan kesehatan dan membantu melakukan kontrol rutin di pelayanan kesehatan yang ada.
\end{abstract}

Kata kunci: Dukungan keluarga, perawatan, lanjut usia, hipertensi

\begin{abstract}
The incidence of hypertension in the world is predicted to increase every year and reach $29.2 \%$ in 2025. Hypertension can threaten public health, especially the elderly because it has the potential to cause complications such as stroke, coronary heart disease and kidney failure so that it requires regular treatment. Old age and hypertension are one of the conditions that are considered as comorbid COVID19, so that it can increase the severity and death of a person. Family support is needed by people with
\end{abstract}


hypertension so that they can carry out the treatment plan that has been determined and comply with the rules of therapy, especially during the COVID-19 pandemic. This study aims to see the relationship between family support and health care efforts for the elderly with hypertension during the COVID-19 pandemic. This was descriptive correlation study with cross sectional design. The number of samples was 96 elderly respondents who suffer from hypertension in Kangkung village, Mranggen, Demak, aged 60 years, currently undergoing anti-hypertensive therapy, routinely taking hypertension treatment at the Puskesmas Mranggen 1 and living with family. The sampling technique used was proportional random sampling technique. Data collection tools using a questionnaire and analyzed using the Chi Square test. The results showed that there were 66 respondents $(68.75 \%)$ who had made good health care efforts. There was good family support of 85 respondents (88.55) there was a relationship between family support and health care efforts for the elderly with hypertension during the COVID-19 pandemic with a $p$ value of $p=0.048$ ( $p$ value <0.05). Based on these results, it was expected elderly hypertension sufferers to continue to regularly carry out health care efforts, especially routine checks in health services even in a state of the COVID-19 pandemic by paying attention to health protocols so as to prevent possible complications. Families always provide motivation and support for hypertensive elderly to always take care health and help carry out routine checks in existing health services.

\section{Keywords: Family support, care, elderly, hypertension}

\section{LATAR BELAKANG}

Salah satu penyakit yang menjadi masalah kesehatan di seluruh dunia adalah hipertensi. Berdasarkan prediksi WHO angka kejadian hipertensi di dunia akan meningkat setiap tahunnya dan mencapai 29,2\% pada tahun 2025(Soesanto and Marzeli, 2020). Hasil Riskesdas 2018 menunjukkan angka prevalensi hipertensi pada penduduk > 18 tahun secara nasional berdasarkan pengukuran sebesar 34,11\% dan $41 \%$ diantaranya tidak rutin melakukan pengukuran dan kontrol kesehatannya(Kemenkes, 2018). Di Jawa Tengah prevalensi penyakit hipertensi sebanyak 8.070.378 penderita atau sebesar 37,5 \%(Dinas Kesehatan Jawa Tengah, 2020). Penderita Hipertensi di Kabupaten Demak sebanyak 309.697 orang dan $19 \%$ diantaranya lanjut usia yang berada di Wilayah kerja Puskesmas Mranggen I(Dinkes Kab. Demak, 2019; Seksi Pencegahan dan Pengendalian Penyakit Tidak Menular dan Kesehatan Jiwa, 2020).

Penyakit hipertensi memiliki hubungan erat dengan bertambahannya usia seseorang dan merupakan penyakit degeneratif, bersifat menahun yang dapat mempengaruhi kualitas hidup serta produktivitas seseorang. Penyakit Hipertensi selain membutuhkan penatalaksanaan dan pengobatan jangka panjang juga melakukan perubahan gaya hidup yang meliputi; menurunkan berat badan, diet sehat, menurunkan konsumsi sodium, mengurangi lemak, melakukan aktivitas fisik, dan mengendalikan stress dengan baik (PK et al., 2018). Hipertensi dapat mengancam kesehatan masyarakat khususnya lanjut usia karena mempunyai potensi yang dapat menyebabkan komplikasi seperti stroke, jantung koroner dan gagal ginjal sehingga memerlukan pengobatan secara rutin. Beberapa penelitian sebelumnya juga menyampaikan bahwa pengobatan hipertensi 
dipengaruhi oleh ketaatan mengkonsumsi obat hipertensi(Saepudin, 2011). Hipertensi merupakan suatu penyakit yang tidak bisa disembuhkan namun harus selalu dikontrol ataupun dikendalikan supaya tidak mengalami komplikasi yang bisa berakhir dengan kematian(Mangendai, Rompas and Hamel, 2017). Selain itu menurut peneliti lainnya dikatakan bahwa ketidak teraturan dalam melakukan perawatan dan pengobatan secara rutin dikarenakan mayoritas penderitanya merasakan bosan untuk melakukan pengobatan karena membutuhkan waktu yang lama dan dapat membebani keluarga(Ihwatun et al., 2020).

Pada bulan Desember 2019 dunia digemparkan oleh munculnya penyakit baru bernama Coronavirus Disease 2019 (COVID-19). Virus ini begitu cepat menyebar ke seluruh penjuru dunia tak terkecuali Indonesia dan pada bulan Maret 2020 WHO menyatakan sebagai pandemi. Severe Acut respiratory Syndrome Coronavirus 2 (SARS-CoV-2) menular dari manusia ke manusia dengan menginfeksi saluran pernafasan melalui percikan (droplet) sehingga menimbulkan penyakit yang disebut dengan Coronavirus Disease 2019 (COVID-19). Sampai dengan akhir bulan mei 2021 jumlah kasus yang terkonfirmasi positif COVID-19 sebanyak 1.821.703 kasus, 11,3\% kasus tersebut diantaranya terjadi pada lanjut usia dan penyakit penyerta yang tertinggi adalah hipertensi sebanyak 50,3\%(COVID-19, 2021). Usia lanjut dan hipertensi merupakan salah satu kondisi yang dianggap sebagai komorbid COVID-19, sehingga dapat meningkatkan tingkat keparahan dan kematian pada seseorang. Pada masa pandemi COVID-19 jumlah kunjungan lanjut usia hipertensi di puskesmas Mranggen I mengalami penurunan dari tahun 2019 sebesar 66\% menjadi $51 \%$ pada tahun 2020(Dinkes Kab. Demak, 2019). Hasil survay yang dilakukan peneliti sebelumnya kepada beberapa lanjut usia yang tidak melakukan kunjungan ulang atau kontrol ke puskesmas dikarenakan rasa takut tertular penyakit COVID-19, sudah merasa sehat, tidak ada keluarga yang mengantar ke puskesmas dan mengingatkan kalau harus melakukan kontrol secara rutin serta adanya anjuran untuk tetap dirumah.

Dukungan keluarga sangat dibutuhkan oleh penderita hipertensi agar dapat melaksanakan rencana perawatan yang telah ditetapkan dan mematuhi aturan terapinya khususnya dimasa pandemi COVID-19. Berdasarkan hasil penelitian sebelumnya dukungan keluarga merupakan salah satu faktor yang terpenting dalam program pengobatan dan pengendalian penyakit hipertensi(Yeni and Husna, 2016). Dukungan keluarga dapat menunjang keberhasilan terapi hipertensi karena memiliki hubungan erat dengan kepatuhan minum obat(Widyaningrum, Retnaningsih and Tamrin, 2019). 


\section{METODE PENELITIAN}

Jenis penelitian ini adalah Deskriptif Korelasi dengan menggunakan desain Cross Sectional. Jumlah sampel sebanyak 96 responden lanjut usia yang menderita hipertensi di desa Kangkung, Mranggen, Demak, berusia $\geq 60$ tahun, sedang menjalani terapi anti hipertensi, rutin melakukan pengobatan hipertensi di Puskesmas Mranggen I dan tinggal bersama keluarga. Teknik pengambilan sampel dengan menggunakan Teknik proporsional random sampling. Jumlah sampel terdiri dari 26 lanjut usia hipertensi dari dusun Senggrong, 28 lanjut usia hipertensi dari dusun Krajan, dan 42 lanjut usia hipertensi dari dusun Karang. Alat pengumpulan data menggunakan kuesioner, dianalisis dengan menggunakan uji Chi Square.

\section{HASIL DAN PEMBAHASAN}

Karakteristik responden pada penelitian ini berdasarkan umur rata-rata 70 tahun $\pm 7,19$, usia terendah adalah 60 tahun dan tertinggi 87 tahun. Sedangkan menurut jenis kelamin sebagian besar adalah perempuan sebanyak 56 orang $(58,3 \%)$. Rata rata lama menderita hipertensi sejak 4,5 tahun $\pm 3,24$, lama menderita hipertensi paling awal adalah 1 tahun dan terlama sejak 17 tahun. Jarak tempuh ke Puskesmas rata-rata 3,97 $\mathrm{km} \pm$ 4,05, jarak terdekat 0,6 km dan terjauh 2,5 km.

Rata-rata upaya perawatan kesehatan yang dilakukan lanjut usia hipertensi dimasa pandemi

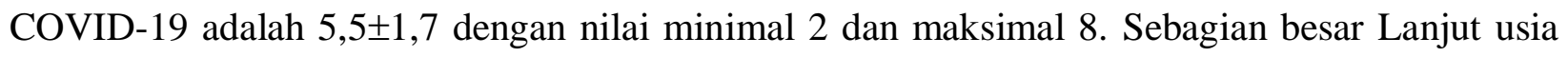
Hipertensi telah melakukan upaya perawatan kesehatan dengan baik yaitu sebesar $68,75 \%$. Hal ini bisa dilihat dalam tabel 1 .

Tabel 1. Deskripsi Upaya Perawatan Kesehatan Lanjut Usia Hipertensi Dimasa Pandemi COVID-19

\begin{tabular}{clcc}
\hline No & Upaya Perawatan Kesehatan & Frekuensi (n) & Persentase (\%) \\
\hline 1 & Kurang & 30 & 31,25 \\
2 & Baik & 66 & 68,75 \\
\hline Jumlah & 96 & 100 \\
\hline
\end{tabular}

Upaya perawatan kesehatan lanjut usia hipertensi dimasa pandemi COVID-19 sebagian besar telah baik, terutama dalam hal: telah mengurangi makanan yang menyebabkan hipertensi, bekerja tidak terlalu berat, minum obat secara teratur dan istirahat cukup. Sedangkan yang masih 
kurang diantaranya adalah: tidak melakukan pemeriksaan secara rutin, tidak bisa berhenti merokok dan sering merasa stres atau cemas.

Rata-rata dukungan yang diberikan keluarga kepada lanjut usia untuk melakukan upaya perawatan kesehatan sebesar 9,04 $\pm 1,96$ dengan nilai minimal 2 dan maksimal 11. Sebagian besar Dukungan yang telah diberikan keluarga kepada lanjut usia hipertensi untuk melakukan upaya perawatan kesehatan adalah baik yaitu sebesar 88,55\%. Hal ini bisa dilihat dalam tabel 2 .

Tabel 2. Deskripsi Dukungan Keluarga kepada Lanjut Usia Hipertensi untuk Melakukan Upaya Perawatan Kesehatan Dimasa Pandemi COVID-19

\begin{tabular}{ccccc}
\hline No & & Dukungan Keluarga & Frekuensi (n) & Persentase $(\%)$ \\
\hline 1 & Kurang & 11 & 11,45 \\
2 & Baik & 85 & 88,55 \\
\hline Jumlah & 96 & 100 \\
\hline
\end{tabular}

Dukungan Keluarga kepada Lanjut Usia Hipertensi untuk melakukan upaya perawatan kesehatan dimasa pandemi COVID-19 sebagian besar telah baik terutama dalam hal: mengingatkan untuk periksa rutin, mengingatkan untuk minum obat, mengingatkan untuk mengurangi garam dan menyarankan untuk selalu berdoa, mengantar periksa, membantu biaya periksa. Sedangkan yang masih kurang diantaranya adalah: mengingatkan untuk berhenti merokok.

Tabel 3. Hubungan antara Dukungan Keluarga dengan Upaya Perawatan Kesehatan Lanjut usia Hipertensi Dimasa Pandemi COVID-19.

\begin{tabular}{|c|c|c|c|c|c|c|c|}
\hline \multirow{3}{*}{ No } & \multirow{3}{*}{$\begin{array}{l}\text { Dukungan } \\
\text { Keluarga }\end{array}$} & \multicolumn{4}{|c|}{ Upaya Perawatan Kesehatan } & \multirow{2}{*}{\multicolumn{2}{|c|}{ Total }} \\
\hline & & \multicolumn{2}{|c|}{ Kurang } & \multicolumn{2}{|c|}{ Baik } & & \\
\hline & & $\mathrm{n}$ & $\%$ & $\mathrm{n}$ & $\%$ & $\mathrm{n}$ & $\%$ \\
\hline 1 & Kurang & 8 & 26,67 & 22 & 73,33 & 30 & 100 \\
\hline 2 & Baik & 22 & 33,33 & 44 & 66,67 & 66 & 100 \\
\hline \multicolumn{2}{|c|}{ Jumlah } & 30 & 31,25 & 66 & 68,75 & 96 & 100 \\
\hline
\end{tabular}

Dari hasil analisis diketahui bahwa ada hubungan antara dukungan keluarga dengan upaya perawatan kesehatan lanjut usia hipertensi dimasa pandemi COVID-19 (p=0,048). Disamping itu dapat diketahui bahwa ada sebanyak 22 lanjut usia hipertensi (73,33\%) telah melakukan upaya perawatan kesehatan dengan baik meskipun kurang mendapatkan dukungan keluarga dan ada 22 lanjut usia hipertensi yang telah mendapatkan dukungan keluarga yang baik tetapi masih kurang 
dalam upaya perawatan kesehatannya. Upaya perawatan kesehatan yang telah dilakukan oleh lanjut usia hipertensi merupakan suatu usaha untuk mengontrol tekanan darahnya agar selalu berada pada batas normal. Upaya perawatan kesehatan yang baik akan membantu mengurangi terjadinya komplikasi. Upaya perawatan kesehatan merupakan suatu tindakan yang dilakukan untuk mencegah dan mengurangi terjadinya komplikasi yang timbul akibat penyakit hipertensi yang tidak terkontrol dengan baik, sehingga upaya perawatan kesehatan tersebut harus dilakukan secara terus-menerus.

Pada masa pandemi COVID-19 ternyata berpengaruh terhadap rutinitas lanjut usia yang menderita hipertensi untuk melakukan upaya perawatan kesehatan secara kontinyu dan masuk dalam katagori kurang sebanyak 31,25 \%. Salah satu upaya perawatan kesehatan yang masih kurang diantaranya adalah tidak melakukan pemeriksaan secara rutin, hal ini disebabkan karena ada rasa takut akan tertular penyakit COVID-19, harus antri lama karena jumlah yang dilayani menjadi berkurang karena penerapan protokol kesehatan, keluarga lebih menyarankan untuk tinggal dirumah saja karena banyaknya kasus lanjut usia yang terkena penyakit COVID-19. Hal senada juga disampaikan oleh peneliti lainnya bahwa penurunan kunjungan dimasa pandemi COVID-19 salah satunya karena kurangnya motivasi penderita dan kurangnya dukungan keluarga(Ayuningtiyas and R, 2020). Penderita hipertensi yang tidak melakukan kontrol rutin maka akan mengalami kesulitan dalam mengendalikan penyakitnya, sehingga tidak mampu memelihara kesehatan dan meningkatkan derajat kesehatan yang lebih baik \{Formatting Citation\}.

Penyakit hipertensi dapat dikontrol dengan merubah pola makan dan gaya hidup. Upaya pencegahan yang dapat dilakukan adalah dengan melakukan pembatasan penggunaan garam hingga 4-6 gr per hari, makanan yang mengandung soda kue, bumbu penyedap dan pengawet makanan, mengurangi makanan yang mengandung kolesterol tinggi (jeroan, kuning telur, cumicumi, kerang, kepiting, coklat, mentega, dan margarin), menghentikan kebiasaan merokok, minum alkohol, olah raga teratur dan menghindari stres(Nuraini, 2015). Seseorang dengan hipertensi memerlukan keyakinan yang baik dalam melakukan upaya perawatan kesehatan agar muncul perilaku yang baik dalam pengelolaan hipertensi. Seseorang yang memiliki keyakinan dan semangat yang baik akan meningkatkan kepatuhan minum obat, meningkatkan aktifitas fisik, tidak merokok, diet rendah garam dan strategi pengelolaan berat badan(Nuraeni, Mirwanti and Anna, 2018). 
Dukungan dari anggota keluarga yang baik memiliki peran penting dalam upaya perawatan kesehatan. Perhatian anggota keluarga mulai dari mengingatkan untuk periksa rutin, mengingatkan untuk minum obat, mengingatkan untuk mengurangi garam dan menyarankan untuk selalu berdoa, mengantar periksa, membantu biaya periksa dan mengingatkan untuk berhenti merokok terbukti lebih baik menjalani upaya perawatan dibandingkan dengan penderita hipertensi yang kurang mendapatkan perhatian dari anggota keluarganya.

Seseorang yang sedang sakit tentunya membutuhkan dukungan dan perhatian dari keluarga khususnya disaat pandemi COVID-19 seperti saat ini, karena keluarga dapat memberikan motivasi kepada anggota keluarganya yang sakit dan mendorong penderita untuk terus berpikir positif terhadap sakitnya dan patuh terhadap pengobatan yang dianjurkan oleh tenaga kesehatan sehingga dirinya mampu mempertahankan kesehatannya. Dukungan sosial merupakan salah satu faktor yang dapat memperkuat seseorang untuk melakukan suatu perilaku kesehatan yang baik, mencegah dari ancaman kesehatan dan dukungan dari keluarga merupakan suatu bentuk dukungan yang sangat kuat pada lanjut usia hipertensi dalam mengontrol kesehatannya. Hal ini juga disampaikan oleh beberapa peneliti lainnya bahwa dukungan keluarga dianggap sebagai kesediaan dari orang-orang terdekat yang berarti bagi hidup seseorang, yang dapat dipercaya mampu menolong, membantu, mendorong, menerima dan menjaga dirinya sehingga dapat menciptakan suatu harmanisasi, kesimbangan finansial, kepatuhan menjalankan terapi dan perawatan serta mencapai psychological well-being(Permata, Dra and Suprapti, no date). Dukungan keluarga yang semakin besar dapat mengurangi resiko terjadinya penyakit hipertensi pada lanjut usia, karena lanjut usia mendapatkan kasih sayang, bantuan dan kepercayaan yang tinggi dari anggota keluarga lainnya yang membuat lanjut usia merasa nyaman, tidak stres dan merasa sehat(Puspita, Oktaviarini and Santik, 2017).

Hasil penelitian ini menunjukkan ada hubungan antara dukungan keluarga dengan upaya perawatan kesehatan lanjut usia hipertensi dimasa pandemi COVID-19. Perubahan perilaku kesehatan seseorang cenderung memerlukan dan dukungan dari keluarga dan masyarakat disekitarnya, apabila perubahan perilaku tersebut bertentangan atau tidak memperoleh dukungan maka ia akan merasa tidak nyaman, sehingga enggan melakukan upaya pencegahan atau tentakan tertentu. Dukungan keluarga yang tinggi akan menjadikan lanjut usia hipertensi akan lebih optimis dalam menghadapi segala permasalahan termasuk melakukan upaya perawatan kesehatan saat ini maupun yang akan datang, lebih terampil dalam memenuhi kebutuhan psikologis dan memiliki 
ketrampilan yang lebih baik sehingga mampu menyelesaikan permasalahan kesehatan dan mengendalikannya. Hasil penelitian ini juga didukung oleh penelitian lainnya bahwa ada hubungan antara dukungan keluarga dengan kepatuhan lanjut usia dalam mengkonsumsi obat anti hipertensi(Rangkuti, Rahayu and Hutapea, 2021). Bentuk dukungan keluarga yang baik lebih banyak disebabkan karena keluarga tidak terikat dengan pekerjaan dan memiliki banyak waktu untuk memperhatikan serta mendampingi penderita hipertensi dibandingkan dengan keluarga yang terikat pekerjaan, mereka memiliki sedikit waktu sehingga dapat menyebabkan ketidakpatuhan dalam mengkonsumsi obat dan upaya perawatan kesehatan lainnya(Oktaviani et al., 2021).

Dukungan keluarga terhadap lanjut usia sangat diperlukan selama lanjut usia tersebut masih mampu memahami makna dukungan tersebut sebagai penyokong kehidupannya, namun seringkali terjadi tidak semua lanjut usia mampu memahami adanya dukungan yang telah diberikan oleh keluarga sehingga menunjukkan rasa tidak puas, menggerutu dan kecewa. Hal ini terjadi karena dukungan yang diberikan tidak cukup, dukungan yang diberikan tidak sesuai dengan kebutuhannya, merasa tidak perlu dibantu. Keadaan ini dapat mengganggu upaya perawatan kesehatan yang seharusnya dilakukan oleh lanjut usia hipertensi.

Dukungan keluarga bisa berupa dukungan emosional merupakan suatu keinginan untuk percaya pada orang lain dan melibatkan kekuatan jasmani sehingga individu menjadi yakin bahwa orang lain dapat memberikan cinta dan kasih sayang kepada dirinya, dukungan Instrumental merupakan dukungan keluarga dalam hal penyediaan sarana prasarana untuk mempermudah atau menolong orang lain termasuk didalamnya memberikan peluang waktu. Dukungan informatif keluarga adalah pemberian informasi kepada anggota keluarga untuk mengatasi masalah kesehatan atau masalah lainnya melalui pemberian nasehat, pengarahan, dan keterangan lain yang dibutuhkan oleh individu yang bersangkutan serta dukungan penilaian berupa peran sosial yang meliputi umpan balik, perbandingan sosial, dan afirmasi atau persetujuan(Friedman, M. M., Bowden, V. R., \& Jones, 2014).

\section{SIMPULAN}

Dari hasil penelitian menunjukkan bahwa sebagian besar lanjut usia hipertensi selama pandemi COVID-19 mempunyai upaya perawatan kesehatan terutama dalam hal: telah mengurangi makanan yang menyebabkan hipertensi, bekerja tidak terlalu berat, minum obat secara 
teratur dan istirahat cukup. Dukungan keluarga yang telah diberikan sebagian besar baik, terutama dalam hal mengingatkan untuk periksa rutin, mengingatkan untuk minum obat, mengingatkan untuk mengurangi garam dan menyarankan untuk selalu berdoa, mengantar periksa, membantu biaya periksa. Ada hubungan antara dukungan keluarga dengan upaya perawatan kesehatan yang dilakukan lanjut usia hipertensi selama pandemi COVID-19. Diharapkan lanjut usia hipertensi penderita agar tetap teratur melakukan upaya perawatan kesehatan khususnya kontrol rutin di pelayanan kesehatan meskipun dalam keadaan pandemi COVID-19 dengan memperhatikan protokol kesehatan sehingga dapat mencegah kemungkinan terjadinya komplikasi. Keluarga selalu memberikan motivasi dan dukungan kepada lanjut usia hipertensi untuk selalu melakukan upaya perawatan kesehatan dan membantu melakukan kontrol rutin di pelayanan kesehatan yang ada.

\section{DAFTAR PUSTAKA}

Ayuningtiyas, R. and R, G. I. (2020). 'Hubungan Motivasi Pasien Prolanis Dengan Frekuensi Kunjungan Prolanis Di Puskesmas Melur Kota Pekanbaru Tahun 2020'. Collaborative Medical Journal (CMJ). LPPM Universitas Abdurrab, 3(3), pp. 117-122. doi: 10.36341/CMJ.V3I3.1673.

COVID-19, S. T. P. (2021) Peta Sebaran COVID-19. Komite Penanganan COVID-19 dan Pemulihan Ekonomi Nasional.

Dinas Kesehatan Jawa Tengah (2020) Profil Kesehatan Provinsi Jawa Tengah Tahun 2019. Semarang: Dinas Kesehatan Provinsi Jawa Tengah.

Dinkes Kab. Demak, P. M. (2019) Laporan SP2TP Puskesmas Mranggen tahun 2019.

Faktor Penyebab Terjadinya Penurunan Jumlah Kunjungan Peserta Program Pengelolaan Penyakit Kronis (Prolanis) Di Puskesmas Minasa Upa Kota Makassar. Jurnal Ilmiah Kesehatan Diagnosis.

Friedman, M. M., Bowden, V. R., \& Jones, E. G. (2014) Buku Ajar Keoerawatan Keluarga (Riset, teori, dan praktik). 5th edn. Jakarta: EGC.

Ihwatun, S. et al. (2020) 'Faktor-Faktor Yang Berhubungan Dengan Kepatuhan Pengobatan Pada Penderita Hipertensi Di Wilayah Kerja Puskesmas Pudakpayung, Kota Semarang', Jurnal Kesehatan Masyarakat (e-Journal), 8(3), pp. 352-359.

Kemenkes, P. (2018) Profile kesehatan Indonesia tahun 2018. Jakarta.

Mangendai, Y., Rompas, S. and Hamel, R. S. (2017). 'Faktor-Faktor Yang Berhubungan Dengan Kepatuhan Berobat Pada Pasien Hipertensi Di Puskesmas Ranotana Weru'. Jurnal Keperawatan, 5(1).

Nuraeni, A., Mirwanti, R. and Anna, A. (2018). 'Upaya Pencegahan dan Perawatan Hipertensi di 
Rumah Melalui Media Pembelajaran Bagi Masyarakat di Kabupaten Pangandaran'. Jurnal Bagimu Negeri, 2(1), pp. 174-178. doi: 10.26638/jbn.554.8651.

Nuraini, B. (2015). Risk Factors Of Hypertension. Jurnal Majority, 4(5).

Oktaviani, N. P. W. et al. (2021). 'Dukungan Keluarga Mengontrol Kepatuhan Minum Obat Anti Hipertensi pada Lansia selama Pandemi Covid 19'. Jurnal Keperawatan, 13(2), pp. 69-78. doi: 10.32583/Keperawatan.V13I2.1474.

Permata, D., Dra, S. ; V. and Suprapti, E. 'Pengaruh Dukungan Keluarga Terhadap Psychological Well-Being Pada Masa Pensiun'.

PK, W.et al. (2018) '2017 ACC/AHA/AAPA/ABC/ACPM/AGS/APhA/ASH/ASPC/NMA/PCNA Guideline for the Prevention, Detection, Evaluation, and Management of High Blood Pressure in Adults: Executive Summary: A Report of the American College of Cardiology/American Heart Association Task Force on Clinical Practice Guidelines', Hypertension (Dallas, Tex.: 1979). Hypertension, 71(6), pp. 1269-1324. doi: 10.1161/HYP.0000000000000066.

Puspita, E., Oktaviarini, E. and Santik, Y. D. P. (2017). 'Peran Keluarga Dan Petugas Kesehatan Dalam Kepatuhan Pengobatan Penderita Hipertensi Di Puskesmas Gunungpati Kota Semarang'. Jurnal Kesehatan Masyarakat Indonesia, 12(2), pp. 25-32.

Rangkuti, W. F. S., Rahayu, H. and Hutapea, B. (2021). 'Dukungan Sosial Keluarga Berhubungan dengan Kepatuhan Diet Pasien Hipertensi'. Jurnal Keperawatan Jiwa (JKJ): Persatuan Perawat Nasional Indonesia, 9(1), pp. 171-178. doi: 10.26714/JKJ.9.1.2021.171-178.

Saepudin, D. (2011). 'Jurnal Farmasi Indonesia: Kepatuhan Penggunaan Obat pada Pasien Hipertensi di Puskesmas. (July 2013), p. Vol 6, No 4, Juli 2013.

Seksi Pencegahan dan Pengendalian Penyakit Tidak Menular dan Kesehatan Jiwa (2020) Profil Kesehatan Kabupaten Demak Tahun 2020. Demak: Dinas Kesehatan Kabupaten Demak.

Soesanto, E. and Marzeli, R. (2020). 'Persepsi Lansia Hipertensi Dan Perilaku Kesehatannya', Jurnal Keperawatan dan Kesehatan Masyarakat Cendekia Utama, 9(3), pp. 244-251. doi: 10.31596/JCU.V9I3.627.

Widyaningrum, D., Retnaningsih, D. and Tamrin, T. (2019). 'Hubungan Dukungan Keluarga Dengan Kepatuhan Minum Obat Pada Lansia Penderita Hipertensi'. Jurnal Ilmu Keperawatan Komunitas. Persatuan Perawat Nasional Indonesia Jawa Tengah, 2(2), pp. 2126. doi: 10.32584/JIKK.V2I2.411.

Yeni, F. and Husna, M. (2016). Dukungan Keluarga Memengaruhi Kepatuhan Pasien Hipertensi'. Jurnal Keperawatan Indonesia, 19(3), pp. 2354-9203. doi: 10.7454/jki.v19i3.471. 